\title{
KEBIJAKAN FORMULASI PIDANA MATI TERHADAP PELAKU TINDAK PIDANA KORUPSI DI INDONESIA
}

\author{
Risva Fauzi Batubara ${ }^{1}$, Barda Nawawi Arief ${ }^{2}$, Eko Soponyono ${ }^{3}$
}

\begin{abstract}
Abstrak
Penelitian ini bertujuan untuk mengkaji dan menganalisis kebijakan formulasi pidana mati terhadap pelaku tindak pidana korupsi di Indonesia saat ini, dan kebijakan formulasi pidananya di masa yang akan datang. Metode penelitian yang digunakan adalah yuridis normatif, dengan menggunakan data sekunder berupa perangkat peraturan perundang-undangan, serta ditunjang dengan data primer berupa penelitian di lapangan. Hasil penelitian menunjukkan bahwa kebijakan formulasi pidana mati terhadap pelaku tindak pidana korupsi di Indonesia saat ini sudah diatur dalam dalam Pasal 2 ayat (2) Undang-Undang No. 31 Tahun 1999 jo Pasal 1 ayat (1) Undang-Undang No. 20 Tahun 2001, namun sampai saat ini masih sangat sulit untuk diterapkan karena masih terdapat banyak kelemahan. Kebijakan formulasi di masa mendatang haruslah mencantumkan kualitas dan kuantitas yang dikorupsi sebagai indikator dalam menjatuhkan pidana mati, termasuk memperjelas masalah posisi/eksistensi pidana mati dalam sistem hukum pidana yang berlaku, syarat-syarat penjatuhan pidana mati bagi koruptor, dan jenis-jenis alternatif pidana mati atau bentuk-bentuk peringanan pidana mati.
\end{abstract}

Kata kunci: Kebijakan Formulasi, Pidana Mati, Tindak Pidana Korupsi

\section{A. Latar Belakang}

Kebijakan formulasi pidana mati terhadap pelaku tindak pidana korupsi telah diatur dalam Undang-Undang No. 31 Tahun 1999 Jo Undangundang No. 20 Tahun 2001 . Pencantuman pidana mati dalam undang-undang tersebut tentunya merupakan fenomena baru dalam upaya pencegahan korupsi di Indonesia karena dengan pencantuman pidana mati tersebut diharapkan akan memberikan efek jera bagi pelaku maupun bagi pelaku lain yang berpotensi sebagai pelaku. Hal ini tentunya dapat dijadikan pegangan bagi aparat penegak hukum untuk dapat menjatuhkan pidana mati bagi pelaku

\footnotetext{
${ }^{1}$ Mahasiswa Program Studi Magister Ilmu Hukum UNDIP

${ }^{2}$ Dosen Program Studi Magister IImu Hukum UNDIP

${ }^{3}$ Dosen Program Studi Magister IImu Hukum UNDIP
} 
tindak pidana korupsi yang memenuhi rumusan Pasal 2 ayat (2) Undangundang No. 31 Tahun 1999 jo Pasal 1 ayat (1) Undang-Undang No. 20 Tahun 2001.

Sejak berlakunya Undang-Undang No. 20 Tahun 2001 tentang Pemberantasan Tindak Pidana Korupsi, Hakim di Indonesia tidak pernah sekalipun menjatuhkan pidana mati tersebut terhadap seorang koruptor. Meskipun, dalam ketentuan perundang-undangan memberikan landasan hukum yang cukup tegas, sehingga belum dapat memberikan efek jera kepada para koruptor lainnya. Berdasarkan latar belakang di atas, maka dapat dirumuskan permasalahannya, antara lain: pertama, bagaimana kebijakan formulasi pidana mati terhadap pelaku tindak pidana korupsi di Indonesia saat ini? Kedua, bagaimana penerapan formulasi pidana mati terhadap pelaku tindak pidana korupsi di Indonesia saat ini? Ketiga, bagaimana kebijakan formulasi pidana mati terhadap pelaku tindak pidana korupsi di Indonesia di masa yang akan datang?

\section{B. Metode Penelitian}

Penelitian ini menggunakan pendekatan yuridis normatif dengan menggunakan data sekunder berupa perangkat peraturan perundang-undangan, serta ditunjang dengan data primer berupa penelitian di lapangan.

\section{Hasil dan Pembahasan}


1. Kebijakan Formulasi Pidana Pidana Mati Terhadap Pelaku Tindak Pidana Korupsi Di Indonesia Saat Ini.

Kebijakan formulasi pidana mati mengandung beberapa kelemahan dan memberi kesan "kekurang seriusan" pembuat Undang-undang untuk menerapkan pidana mati. Beberapa kelemahan itu dapat dijelaskan sebagai berikut: ${ }^{4}$

a. Pidana mati sebagai pemberatan pidana, hanya diancamkan untuk tindak pidana korupsi tertentu dalam Pasal 2 ayat (1), yaitu: "melakukan perbuatan memperkaya diri sendiri/ oranglain/ korporasi secara melawan hukum". Jadi tidak ditujukan kepada semua bentuk tindak pidana korupsi, padahal dalam "Penjelasan Umum" dinyatakan, bahwa tujuan dibuatnya Undang-undang No. 31 Tahun 1999 ini (sebagai pengganti Undang-undang No. 3 Tahun 1971) adalah untuk memberantas "setiap bentuk tindak pidana korupsi". Dengan diancamkannya pidana mati (sebagai pemberatan pidana) hanya untuk tindak pidana korupsi dalam Pasal 2, berarti pidana mati tidak mungkin dapat dijatuhkan terhadap tindak pidana korupsi lainnya;

b. Menurut Pasal 2 ayat (2), pidana mati merupakan pemberatan pidana terhadap delik dalam Pasal 2 ayat (1) yang diancam dengan pidana seumur hidup atau penjara 20 tahun. Di dalam Undang-undang No. 31 Tahun 1999 jo Undang-undang No. 20 Tahun 2001, tindak pidana korupsi yang diancam dengan pidana seumur hidup atau maksimum

${ }^{4}$ Romli Atmasasmita dalam Indriyanto Seno Adji, 2001, Pidana mati Bagi Koruptor Sebagai Upaya Pemberantasan Korupsi, Jakarta, Jurnal Keadilan, hlm 57-58 
penjara 20 tahun tidak hanya terdapat dalam Pasal 2, tetapi terdapat juga dalam Pasal 3: penyalahgunaan kewenangan/ kesempatan/ sarana karena jabatan atau kedudukan; Pasal 12: penerimaan suap (suap pasif) oleh pegawai negeri/ penyelenggara Negara, hakim, dan advokat. Oleh karena itu, dirasakan janggal kalau pidana mati hanya diancamkan terhadap delik dalam Pasal 2. Padahal dalam pandangan masyarakat dan dilihat dari hakikat korupsi sebagai delik jabatan, perbuatan "menyalahgunakan kewenangan jabatan/kedudukan" (Pasal 3) dan "penerimaan suap oleh pegawai negeri/penyelenggara negara, hakim, dan advokat" (Pasal 12) dirasakan lebih tercela daripada "memperkaya diri" (Pasal 2); setidak-tidaknya harus dipandang sama berat, dan oleh karenanya juga layak untuk diancam dengan pidana mati, terlebih delik penyuapan justru paling menonjol dalam berbagai kasus korupsi selama ini;

c. Kelemahan lain, berkaitan dengan formulasi "keadaan tertentu" yang menjadi alasan pemberatan pidana untuk dapat dijatuhkannya pidana mati. Dalam berbagai formulasi Undang-undang, "keadaan tertentu" yang menjadi alasan pemberatan pidana pada umumnya dirumuskan secara tegas dalam perumusan delik yang bersangkutan (misalnya pemberatan pidana untuk penganiayaan dalam Pasal 356 KUHP dan pemberatan pidana untuk pencurian dalam Pasal 365 KUHP). Namun dalam Pasal 2 ayat (2) Undang-undang No. 31 Tahun 1999, "keadaan tertentu" yang menjadi alasan pemberatan pidana itu tidak dirumuskan 
secara tegas dalam perumusan pasal, tetapi hanya dimasukkan dalam “penjelasan Pasal 2";

d. Pemberatan pidana mati dalam Pasal 2 ayat (2) Undang-undang No. 31 Tahun 1999 hanya ditujukan pada “orang". Tidak ada pemberatan pidana terhadap korporasi yang melakukan tindak pidana korupsi dalam "keadaan-keadaan tertentu" sebagaimana disebutkan di atas. Walaupun pidana mati tidak bisa dikenakan pada korporasi, namun seharusnya tersedia juga pemberatan pidana untuk korporasi yang bobotnya dapat diidentikkan dengan pidana mati. Misalnya, pencabutan izin usaha selama-lamanya atau pembubaran/penutupan korporasi.

\section{Penerapan Formulasi Pidana Mati Terhadap Pelaku Tindak Pidana}

\section{Korupsi Di Indonesia Saat Ini.}

Adanya ancaman pidana mati dalam Undang-Undang No.31 Tahun 1999 itu menunjukkan keseriusan pemerintah dan DPR pada waktu itu untuk memberantas korupsi. Namun, dalam kenyataannya, sudah sebelas tahun lebih sejak keluarnya Undang-Undang No. 31 Tahun 1999, sampai saat ini belum ada seorang koruptor pun yang dijatuhi pidana mati. Berbeda halnya dengan pelaku tindak pidana narkotika yang sudah banyak (puluhan) dijatuhi pidana mati. $^{5}$

\footnotetext{
${ }^{5}$ Barda Nawawi Arief, Pidana Mati, Perspektif Global, Pembaharuan Hukum Pidana dan Alternatif Pidana Untuk Koruptor, Semarang, Pustaka Magister, hlm 54
} 
Sinintha Yuliansih Sibarani ${ }^{6}$ mengemukakan bahwa sampai saat ini belum ada satupun kasus tindak pidana korupsi yang dijatuhi hukuman mati. Hal ini didasarkan karena pengertian hakim yang berbeda tentang tindak pidana korupsi itu sendiri, sebagian hakim memandang bahwa tindak pidana korupsi merupakan kejahatan yang luar biasa (extraordinary crime), bersifat sistemik dan endemik dengan dampak yang sangat luas (systematic and widespread), sehingga penanganannya perlu upaya/langkah-langkah luar biasa yang komprehensif (comprehensive extraordinary measures), termasuk pidana mati. Sebagian lagi memandang hanya merupakan tindak pidana biasa yang upaya penanganannya tidak perlu memakai pidana mati. Pemikiran ini didasarkan pada Hak Asasi Manusia (HAM).

3. Kebijakan Formulasi Pidana Pidana Mati Terhadap Pelaku Tindak Pidana Korupsi Di Indonesia Di Masa Yang Akan Datang.

Mengingat adanya berbagai kelemahan formulasi pidana mati seperti diuraikan di atas, maka sekiranya kebijakan pidana mati akan tetap digunakan untuk menghadapi tindak pidana korupsi (tipikor), sehingga perlu dilakukan amandemen atau reformulasi ketentuan pidana mati dalam perundangundangan.

Reformulasi ketentuan pidana mati untuk koruptor terkait dengan beberapa masalah, antara lain:

a. Posisi/status/eksistensi pidana mati dalam sistem hukum pidana yang berlaku saat ini;

\footnotetext{
${ }^{6}$ Wawancara dengan Hakim Pengadilan Tindak Pidana Korupsi pada Pengadilan Negeri Semarang pada tanggal 24 Juli 2014
} 
b. Syarat-syarat penjatuhan pidana mati bagi koruptor;

c. Jenis-jenis alternatif pidana mati atau bentuk-bentuk peringanan pidana mati.

Pidana mati dalam hukum positif selama ini merupakan salah satu pidana pokok. Namun, dalam kebijakan formulasi selama ini, pidana mati tidak pernah dirumuskan secara tunggal (yang mengandung sifat imperatif/absolut), tetapi selalu dirumuskan secara alternatif dengan jenis-jenis pidana pokok lainnya dan hanya diancamkan untuk delik-delik tertentu. Jadi, walaupun pidana mati merupakan pidana pokok, namun hakikatnya merupakan "pidana pokok yang bersifat khusus dan selalu diancamkan secara alternatif". Dengan perumusan alternatif demikian, berarti pidana mati dipandang sebagai alternatif terakhir atau "upaya terakhir" (the last resort) dalam melindungi masyarakat.

Hakikat pidana mati yang bersifat alternatif dan tidak absolut itu, nampaknya sesuai dengan hasil penelitian maupun dari sudut pandang religius. Dari hasil penelitian yang pernah dilakukan oleh Fakultas Hukum UNDIP bekerjasama dengan Kejaksaan Agung, kebanyakan responden (56,63 \%) menyatakan, perlunya pidana mati dipertahankan sebagai "sarana terakhir melindungi masyarakat dari penjahat sadis dan sukar diperbaiki lagi". ${ }^{7}$ Dari sudut pandang religius (Islam), tentunya akan diuraikan tersendiri. Namun, penulis berpendapat, Islam pun berpandangan relatif tentang pidana mati karena lebih mendahulukan permaafan dan perdamaian.

7 Laporan Penelitian, 1981/1982, Ancaman Hukuman Mati Dalam Sistem Pemidanaan, Kerjasama Kejaksaan Agung RI dan FH UNDIP, hlm 13 
Bertolak dari hakikat pidana mati sebagai pidana pokok yang bersifat khusus dan sebagai upaya terakhir yang bersifat alternatif, maka kebijakan formulasi pidana mati untuk koruptor seyogyanya disusun dengan ramburambu sebagai berikut:

a. Pidana mati diancamkan sebagai pemberatan pidana untuk delik-delik korupsi tertentu yang dipandang sangat tercela dan sangat merugikan dan merusak kehidupan masyarakat luas (berbangsa/bernegara);

b. Kriteria sangat tercela dan sangat merugikan dapat didasarkan pada:

1) Kriteria objektif, antara lain :

a) Kualitas bobot delik (maksimum pidana yang diancamkan);

b) Cara dan kondisi perbuatan dilakukan atau ada faktor pemberatan pidana;

c) Keseriusan akibat yang ditimbulkan (nyata maupun poten-sial).

2) Kriteria substantif/materiil, antara lain :

a) Nilai kerugian yang ditimbulkan atau hasil yang diperoleh-nya;

b) Objek/sasaran delik (misal dana pembangunan atau dana untuk kepentingan fital rakyat banyak);

3) Kriteria status subjek/pelaku : misal pejabat; orang yang bertindak sebagai pejabat atau yang berpura-pura (mengaku) sebagai pejabat (Use of Pretended Authority); petugas/pegawai yang mempunyai posisi; pemegang fungsi negara atau pelayanan publik; personil negara yg mengambil keuntungan dari instansi/jabatannya; pejabat yang memperdagangkan pengaruh jabatannya (Traffic in Official Influence); 
memperdagangkan pengaruh pribadi (Traffic in Private Influence); orang yang memanfaatkan pejabat/fungsionaris tsb.

c. Faktor-faktor pemberatan pidana atau kriteria untuk adanya pidana mati itu, dirumuskan secara eksplisit dalam perumusan delik atau dirumuskan sebagai pedoman umum untuk penjatuhan pidana mati.

\section{Simpulan}

Kebijakan formulasi pidana mati terhadap pelaku tindak pidana korupsi di Indonesia saat ini masih banyak terdapat kelemahan-kelemahan, seperti alasan teknis juridisnya, sehingga masih sangat sulit untuk diterapkan saat ini. Belum ada satupun kasus tindak pidana korupsi yang dijatuhi pidana mati, hal ini didasarkan karena perumusan pidana mati terhadap pelaku tindak pidana korupsi hanya diatur dalam delik Pasal 2 ayat (2) Undang-Undang No. 31 Tahun 1999 jo Pasal 1 ayat (1) Undang-Undang No. 20 Tahun 2001, dan syarat penjatuhannya sangat sulit untuk diterapkan.

Di dalam reformulasi kebijakan formulasi pidana mati terhadap pelaku tindak pidana korupsi di Indonesia di masa yang akan datang, haruslah mencantumkan kualitas dan kuantitas yang dikorupsi sebagai indikator dalam menjatuhkan pidana mati, termasuk memperjelas masalah posisi/eksistensi pidana mati dalam sistem hukum pidana yang berlaku, syarat-syarat penjatuhan pidana mati bagi koruptor, dan jenis-jenis alternatif pidana mati atau bentuk-bentuk peringanan pidana mati.

\section{Daftar Pustaka}

Laporan Penelitian, 1981/1982, Ancaman Hukuman Mati Dalam Sistem Pemidanaan, Kerjasama Kejaksaan Agung RI dan FH UNDIP 
Nawawi Arief, Barda, 2012, Pidana Mati Perspektif Global, Pembaharuan hukum Pidana dan Alternatif Pidana untuk Koruptor, Semarang: Pustaka Magister

Seno Adji, Indriyanto, 2001, Pidana mati Bagi Koruptor Sebagai Upaya Pemberantasan Korupsi, Jakarta: Jurnal Keadilan 